\title{
Ikke-audiologiske helseeffekter av støy
}

\author{
Gunn Marit Aasvang og Norun Hjertager Krog \\ Divisjon for miljømedisin, Nasjonalt folkehelseinstitutt, Oslo \\ Korrespondanse: Norun Hjertager Krog, Divisjon for miljømedisin, Nasjonalt folkehelseinstitutt, Postboks 4404 Nydalen, 0403 Oslo \\ Telefon: 22042592 Telefax: 22042686 E-post: norun.krog@fhi.no Ekspress post: Geitmyrsveien 75, 0462 Oslo
}

\begin{abstract}
SAMMENDRAG
Denne artikkelen oppsummerer eksisterende kunnskap om helsevirkninger av miljøstøy. Nedsatt hørsel som følge av eksponering for høye lydnivåer blant annet i yrkessammenheng er godt dokumentert, og vil ikke omtales i særlig grad. Denne artikkelen vil først og fremst fokusere på ikke-hørselsrelaterte virkninger av den støy som vi har i omgivelsene, hvor de vanligste støykildene er fra samferdsel og industri. Selv om støyens virkninger på spesielt sårbare grupper, som for eksempel barn, er et viktig tema, vil helsevirkningene som omtales her først og fremst være gjeldende for en generell voksen befolkning. Negative helseeffekter av støy er knyttet til støy som en fysiologisk aktiverende stressfaktor som påvirker adferd, trivsel, kommunikasjon, hvile og søvn. Nyere studier antyder også en sammenheng mellom støy og økt risiko for hjerte-karsykdom.
\end{abstract}

\section{Aasvang GM, Krog NH. Non-audiological health effects of noise. Nor J Epidemiol 2004; 14 (2): 167-175. \\ ENGLISH SUMMARY}

This paper summarises existing knowledge about health effects of environmental noise. Reduced hearing due to exposure to high sound pressure levels, for instance in the work-place, is well documented, and is not a topic of this presentation. The paper focuses on non-audiological effects of environmental noise. Although effects of noise on especially vulnerable groups such as children are important issues, this article focuses on the effects that can be demonstrated in the general population. The most common sources of environmental noise are transport and industry. Adverse health effects are related to noise as a physiologically activating stress factor that influences behaviour, well-being, rest and sleep. Some recent studies do also indicate that there may be a relationship between noise and increased risk of cardiovascular disease.

\section{INTRODUKSJON}

Støy defineres ofte som uønsket lyd. De fleste har opplevd at støy er forstyrrende, for eksempel i samtale med andre, i konsentrasjon om skolearbeid og andre oppgaver, eller når man skal hvile eller sove. Støy kan også forstyrre TV-titting, hemme muligheten for å ha åpne vinduer, og begrense bruk av utendørsarealer. Aktivitetsforstyrrelser som dette kan føre til at man føler seg plaget av støy, spesielt dersom man er utsatt for støy over lengre tid, der man bor eller på arbeidsplassen. Støyplage er den mest utbredte og veldokumenterte effekten av støy (1). Bortsett fra støyrelaterte hørselsskader, er det ikke påvist patologisk tilstand hvor støyen er hovedårsak. Flere studier antyder imidlertid at støy kan bidra til subjektive helseplager og stressrelaterte sykdommer.

Fra miljømyndighetenes side betraktes støy som forurensning, og nasjonale grenseverdier for støy er hjemlet i Forurensningsloven. I undersøkelser som sammenligner folks opplevelse av forskjellige typer miljøproblemer er støy funnet å være blant de viktigste problemene (2).

Den vitenskapelig baserte kunnskapen man har om negative virkninger av støy baseres hovedsakelig på to typer studier: eksperimentelle studier og befolknings- undersøkelser. Som eksempler kan nevnes at svært mange studier av hvordan støy forstyrrer nattesøvn er gjennomført som kontrollerte studier i søvnlaboratorier. Undersøkelser av støyplage er hovedsakelig gjort som befolkningsundersøkelser, enten ved hjelp av spørreskjemaer eller telefonintervjuer. I de fleste studier analyseres virkningene av støy i forhold til en eller flere akustiske parametre. En mye brukt parameter for å beskrive støyeksponering er den gjennomsnittlige lydenergien over en bestemt tidsperiode (LpAekv,t). Støynivået kan beskrives samlet over et helt døgn, deler av døgnet (f.eks. natt) eller for enkelthendelser (maksimalnivå, LpAFmaks). I tillegg benyttes enkle frekvensveiekurver som er basert på hørselens følsomhet. Støynivået for en gitt adresse beregnes på bakgrunn av en rekke parametre som trafikktellinger, type kjøretøy, hastighet, terrengdempning, avstand til bolig etc.

De umiddelbare virkningene av støy, som forstyrrelser av blant annet kommunikasjon og søvn er godt dokumentert, mens kunnskap om type og omfang av mulige langtidsvirkninger er mangelfull. Fordi det er store variasjoner i menneskers reaksjoner på støy kan man trolig ikke snakke om en terskel for negative virkninger. På bakgrunn av en rekke studier er det likevel gjort anbefalinger $\mathrm{i}$ forhold til blant annet å begrense 
støyplage og støyinduserte søvnforstyrrelser. For å unngå sterk støyplage bør ikke støynivået utenfor fasade overstige $55 \mathrm{~dB}$ (LpAekv,24h). Støynivået i soverom om natten bør ikke være høyere enn $30 \mathrm{~dB}$ (LpAekv,8h) for jevn støy, og maksimalt støynivå bør ikke overskride $45 \mathrm{~dB}$ (LpAFmaks), for å unngå redusert søvnkvalitet. Ytterligere anbefalinger publisert på vegne av Verdens helseorganisasjon finnes i "Guidelines for Community Noise" (3).

I Norge er det beregnet at ca. 1,5 millioner mennesker er utsatt for døgnekvivalente støynivåer over 55 $\mathrm{dB}$ ved boligen. I forbindelse med levekårsundersøkelsen i 2001 (4) ble det stilt spørsmål om plage fra vegtrafikk-, fly-, tog-, og industristøy. Flest, dvs. 12\%, var noe eller meget plaget av vegtrafikkstøy ute ved boligen, 5\% var tilsvarende plaget av flystøy, 3\% av togstøy og $4 \%$ av industristøy.

Støyplage er den parameteren som norske myndigheter forholder seg til i kartlegging av støyproblemet, støylovgivning og handlingsplaner for å redusere negative virkninger av støy. Et nasjonalt mål er å redusere støyplagene med 25\% innen 2010 i forhold til 1999. Som et ledd i dette har regelverk som omfatter støy gjennomgått en omfattende revisjon, samtidig som et nytt EU-direktiv for støy også skal implementeres i norsk lovgivning.

Overvåkingen av utviklingen i støyplage i Norge skjer ved estimering av støynivå fra forskjellige kilder, ikke ved direkte målinger av støyplage. Plagegrad utledes fra etablerte statistiske sammenhenger mellom støynivå og støyplage, som i noen tilfeller vil være beheftet med stor usikkerhet. Det er gjort beregninger av støyplage fra vegtrafikk, jernbane, luftfart, bygg og anlegg, industri og annen næringsvirksomhet, skytebaner og motorsportbaner. Støykilder som skytefelt, produkter som gressklippere og snøscootere, trikk og T-bane er foreløpig ikke kartlagt (5). Noen støykilder er helt utelukket ved denne beregningsmetoden, som for eksempel støy fra naboer, musikkanlegg, VVS, og tekniske installasjoner i bolig. I tillegg begrenser beregningene seg til å gjelde for støyplage i bolig. Støyplage i for eksempel en arbeids-, skole- eller friluftssituasjon er ikke inkludert. Det vil si at man må anta at den samlede støyplagen i Norge egentlig er høyere enn det dagens beregninger tilsier. Det er behov for flere undersøkelser som måler støyplage direkte, spesielt for de kilder og situasjoner hvor man mangler kunnskap. Men det vil også være behov for supplerende unders $\varnothing$ kelser som måler støyplagen direkte, fordi støyplagen kan påvirkes av andre forhold enn det de etablerte dose-responskurvene fanger opp. Dose-responssammenhengene er basert på studier fra en stabil støysituasjon, mens det for eksempel er indikasjoner i litteraturen på at en markert endring i støyeksponering i et område kan føre til en større endring i plage enn det disse dose-responssammenhengene forutsier (6-11).

I følge Verdens helseorganisasjons (WHO) utvidede helsebegrep er helse "ikke bare fravær av sykdom og svakhet, men en tilstand av fullstendig fysisk, psy- kisk og sosialt velvære" (12). Det er indikasjoner på at støy, i større eller mindre grad, kan påvirke helsen i en hver betydning av begrepet: i form av negativ effekt på både fysisk, psykisk og sosialt velvære, og også som en mulig medvirkende faktor i utvikling av sykdom. Det siste er imidlertid i mindre grad dokumentert.

Verdens helseorganisasjon arbeider med å utvikle støy- og helseindikatorer for bedre å overvåke støyproblemet. Disse indikatorene som skal baseres på kunnskap om dose-responssammenhenger, skal også brukes til utvikling av handlingsplaner og tiltak for å redusere de negative effektene av støy. I første omgang er det utviklet indikatorer som er knyttet til støyplage og støyinduserte søvnforstyrrelser. Det er også et mål å komme frem til indikatorer for andre helsevirkninger, blant annet risiko for kardiovaskulær sykdom.

Vi vil i denne artikkelen se nærmere på eksisterende kunnskap om helsevirkninger av støy. Vi konsentrerer oss om effektene av den typen støy som er mest utbredt i vårt bomiljø. Det vil si støy fra forskjellige typer samferdselskilder. Eksponeringsnivåer og karakteren av denne typen støy er ikke slik at den utgjør risiko for hørselsskade. Vi vil derfor ikke omtale negative virkninger av støy på hørselen i noen særlig grad. Nedsatt hørsel er derimot en godt dokumentert effekt som følge av eksponering for høye lydnivåer blant annet i yrkessammenheng. Framstillingen konsentrerer seg om negative effekter på en generell voksen befolkning.

\section{HVIS STØY GIR HELSESKADE, HVA KAN SÅ MEKANISMENE VARE?}

Hørselsinntrykk skapes ved at lydtrykkvariasjoner oppfanges av det ytre øret og setter trommehinnen til å vibrere i takt med variasjonene i lydtrykk. Vibrasjonene overføres mekanisk via mellomøret til hårcellene i det indre øret. Disse cellene omdanner svingningene til elektriske nerveimpulser som videresendes via hørselsnerven og hjernestammen til spesifikke områder i hjernebarken hvor senteret for bevisst lydoppfattelse befinner seg.

Fra et evolusjonært synspunkt har det vært hensiktsmessig som en overlevelsesmekanisme, å reagere akutt på lyder uten å involvere høyere hjernesentra. Nerveforbindelser går derfor fra det indre øret også til celler på et "lavere nivå" i hjernestammen. Dette området som er kalt retikulærsubstansen, er involvert $i$ kontroll av flere grunnleggende fysiologiske mekanismer som regulering av puls, blodtrykk, hormonproduksjon og respirasjon. Disse mekanismene er også knyttet til refleksresponser på lyd som et mulig varselsignal. De fysiologiske systemene som aktiveres gir en økning i hjertefrekvens og blodtrykk samt økte nivåer av hormonene adrenalin, noradrenalin og kortisol. Disse endringene er typisk for enhver situasjon hvor kroppen settes i alarmberedskap. Dersom støyeksponeringen er forbigående vil de fysiologiske responsene normalt gå tilbake til samme nivå som før eksponeringen. 
Hørselsskade som følge av støy er en direkte irreversibel virkning av høye lydtrykknivåer på celler i det indre øret. Andre negative virkninger av støy er således indirekte og mekanismene mer kompliserte (figur 1). To ulike indirekte veier kan tenkes, hvor den ene involverer høyere hjernesentra, og er en bevisst prosess som går via selvopplevd støyplage. Den andre er ubevisst, for eksempel virkninger under søvn. Figur 1 viser en teoretisk oversikt over mulige direkte og indirekte virkninger av støy (13). Modellen er presentert som et teoretisk utgangspunkt for å undersøke sammenhenger mellom støyeksponering som en stressfaktor og virkninger på helse, med hjerte-karsykdom som mulig utfall. Modellen er enkel og inkluderer ikke mulige samvirkende og motvirkende faktorer. Slike faktorer vil imidlertid diskuteres under omtalen av de ulike virkningene av støy.

\section{STØY SOM STRESSFAKTOR}

Støy kan betraktes som en stressfaktor, noe som får støtte både i eksperimentelle studier og befolkningsundersøkelser (14). De umiddelbare fysiologiske responsene på støy som nevnt ovenfor, er også typiske reaksjoner på stress; det er påvist blodtrykksøkning og pulsendring samt endringer i nivå av stresshormonene adrenalin, noradrenalin og kortisol (figur 1). Det må skilles mellom den umiddelbare effekten av plutselige høye lyder og effekten av støyeksponering over lengre tid. Selv om kroppen reagerer umiddelbart med en kortvarig økning i blant annet hjertefrekvens og blodtrykk når den blir utsatt for brå, høye lyder, er dette en normal aktiveringsreaksjon som hos ellers friske individer ikke har noen skadelig effekt (15). Hvis det allerede foreligger en høy risiko for hjerteinfarkt, forårsaket av sykdomsprosesser som har pågått over lang tid, kan en slik fysiologisk aktivering utløse et infarkt (16). Det er imidlertid den fysiologiske aktiveringen som vedvarer over lengre tid, som kan føre til sykdom (17). En vedvarende aktivering vil særlig kunne føre til sykdom hos individer som er genetisk disponert, eller er utsatt for spesielle miljømessige faktorer.

En stressreaksjon er ubehagelig og personen som opplever stress vil prøve ut strategier for å fjerne reaksjonen og kilden til stressreaksjonen. En sentral mekanisme for håndtering av stress er mestring. Mestring er definert som positiv responsforventning, det vil si at individet har kontroll over begivenhetene, vet at det har kontroll og samtidig at kontrollen fører til et positivt resultat. Det motsatte av mestring er håpløshet, som kan beskrives som en negativ responsforventning. Når et individ ikke har noen kontroll eller påvirkning over situasjonen utvikles hjelpeløshet. Det er funnet en sammenheng mellom selvopplevd kontroll med støy og enkelte virkninger av støy som for eksempel søvnforstyrrelser, noe som kan gi støtte til hypotesen om at lært hjelpeløshet bidrar til helseskadelige virkninger av støy (18). Fra dyremodeller vet man at det er stressede situasjoner der forsøksdyrene ikke har noen mulighet for mestring som fører til mavesår, hypertensjon og hjerteinfarkt (15).

Det er foreslått at støyplage kan være en mediator mellom støyeksponering og mulige stressrelaterte helsevirkninger av støy som for eksempel hjertekarsykdom (figur 1) (19). Teorier og modeller som presenterer støy som en stressfaktor antyder at mulige konsekvenser for helse er mer relatert til støyplage eller andre mål på subjektiv oppfattelse av støy enn det objektive målet på støyeksponering $(20,21)$.

\section{StøyPlage}

Selv om "støyplage" er det mest brukte effektmålet i støyforskningen, er det et begrep uten klar og entydig betydning. Guski med flere (22) undersøkte hva et utvalg internasjonale støyeksperter la i begrepet. Resultatet var sprikende. Men begrepet synes å ha to hovedaspekter: Det ene er aktivitetsforstyrrelse, det andre er et evaluerende aspekt som kan beskrives i termer som ergrelse, ubehagelighet, og det at det "går en på nervene". Disse to hovedaspektene finner vi igjen $i$ figur 1.

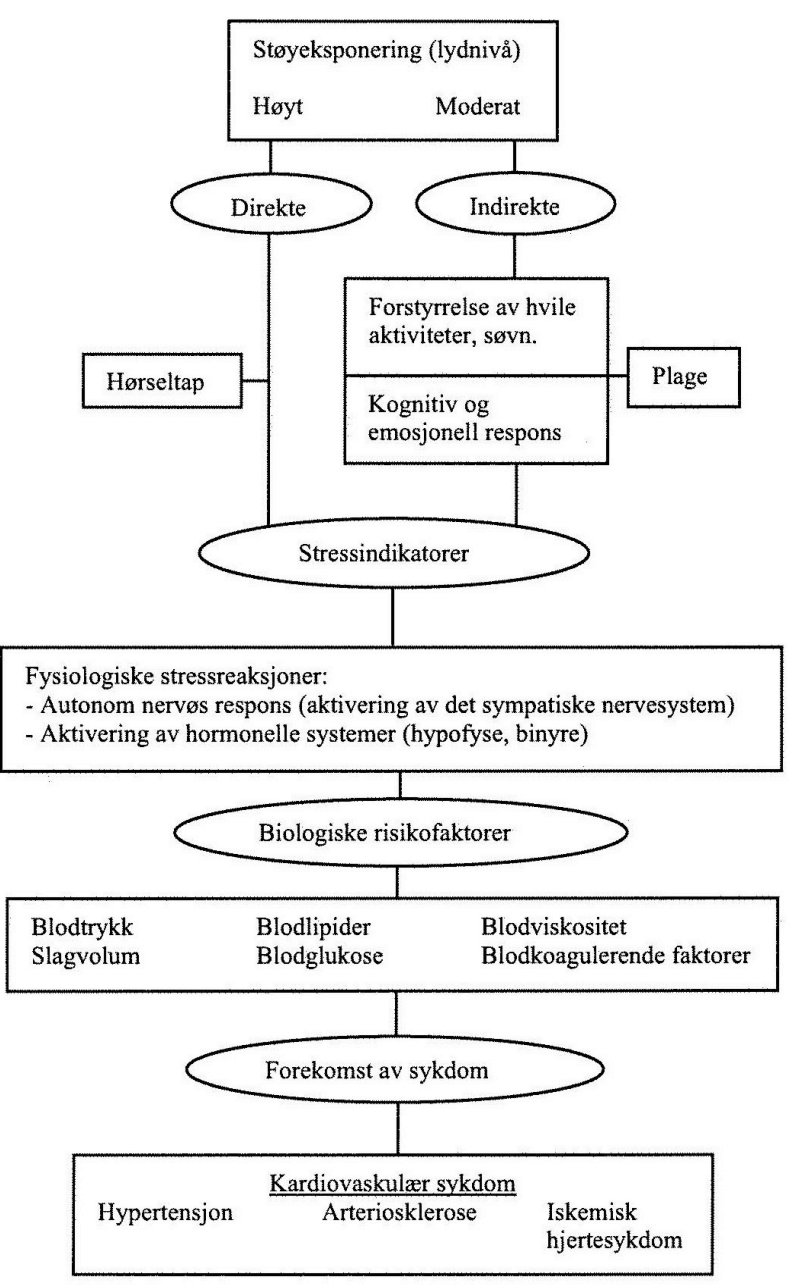

Figur 1. Reaksjonsskjema ment for hypotesetesting i epidemiologiske studier av støy og negative helsevirkninger (13). 
I følge Finegold (23) ble plage-begrepet tatt i bruk som en enhetlig indikator på den samlede responsen på miljøstøy da støyproblemene begynte å melde seg $\mathrm{i}$ USA på 50-tallet. Finegold poengterer at plage er noe mer enn "svak irritasjon". Støyplagen kan bety en markant forverring av livskvaliteten, og den kan føre til andre negative helseeffekter gjennom fysiologiske stressmekanismer (23).

Både forskning og forvaltning $\mathrm{i}$ forhold til støyplage har vært bygget på antagelser om enkle sammenhenger mellom eksponering og respons. Det mest brukte studiedesignet er tverrsnittsstudier hvor støyplage registrert ved spørreskjemaer eller intervjuer i en støyeksponert befolkning, kombineres med støymålinger eller beregninger av eksponering utendørs ved mest eksponerte fasade av boligen. Schultz' (24) klassiske sammenstillende analyse av slike studier viste en stor grad av konsistens i resultatene fra flere slike studier. Den dose-responskurven Schultz kom frem til er basert på en kombinasjon av data fra flere samferdselskilder. Andel "highly annoyed" (svært plaget) ble benyttet som responsmål av Schultz (24), og er det responsmålet det til nå har vært fokusert mest på. Også senere oppdateringer av Schultz' kurve har vist en stor grad av overensstemmelse med de opprinnelige resultatene (23). Gjennom analyse av et større materiale har imidlertid Miedema (25) kommet frem til separate dose-responskurver for støy fra fly, veg og tog. Flystøy kom ut i Miedemas analyser som noe mer plagsom enn vegtrafikkstøy, mens togstøy ga minst plage. Forskjellene er likevel ikke markante, og Finegold (23) stiller spørsmål ved om de egentlig er store nok til å rettferdiggjøre separate kurver. Usikkerheten i både eksponeringsmål og responsmål er stor. Det er også store individuelle variasjoner i reaksjoner på en gitt eksponering, særlig ved moderate nivåer.

I de senere årene har den enkle dose-responsmodellen i økende grad blitt problematisert. Det er vist at ikke-akustiske variabler som holdning til støykilden og støysensitivitet påvirker støyplagen vel så mye som selve støyeksponeringen $(26,27)$. Man har søkt å forbedre forklaringsmodellene ved å studere en rekke kontekstuelle betingelser for støyplage. Slike kontekstuelle faktorer er utelatt i den forenklede fremstillingen i figur 1, men vil ha betydning for helseutfallet av støyeksponeringen fordi de kan virke inn på både eksponering og plage. Et nytt område av støyforskningen har satt fokus på det som har fått betegnelsen "soundscape," eller "lydlandskap." Begrepet omfatter både akustiske variabler og persepsjonen av lydene. Lydlandskapsforskningen søker å finne fram til en bedre karakterisering av både eksponeringssituasjonen og av responsen, medregnet andre helsekonsekvenser enn støyplage, gjennom et mer helhetlig perspektiv på den støyutsatte og hans/hennes omgivelser. Eksempelvis har man studert betydningen av tilgang på en stille side av boligen. I en svensk studie fant man at det å ha en stille side av boligen reduserte støyplagen med 10$20 \%$ (avhengig av støynivå), når man sammenlignet med en kontrollgruppe som hadde tilsvarende eksponeringsnivåer ved mest eksponerte fasade, men ingen stille side av boligen (28). Man har også funnet at støyplagen påvirkes av støysituasjonen i det umiddelbare nabolag til boligen (29). Lydlandskapsforskningen er særlig løfterik i forhold til forebyggende tiltak, fordi den tar tak i variabler som det går an for myndigheter og planleggere å gjøre noe med; for eksempel dette å sørge for at boliger har en stille side. Flere studier har vist at det er begrensningen av muligheten til å ha vinduer åpne, samt begrensninger på bruk av utendørsarealer som bidrar mest til støyplagen $(28,30$, 31). Öhrström (28) nevner god isolasjon av boligene som en mulig årsak til at utendørsaktivitetene er mest berørt i hennes studie. Med lukkede vinduer forstyrres innendørsaktiviteter i mindre grad av støy utenfra. Men støyplagen knyttet til nettopp det å måtte holde vinduene lukket viser at "roen" ikke er uten kostnader.

Utearealene er vanskelig å skjerme godt mot støy. Det gjelder ikke bare folks uteplasser og hager, men også parker og andre rekreasjonsområder. Undersøkelser viser at en viktig grunn til å oppsøke naturområder nettopp er det å "oppleve naturens stillhet", og "komme vekk fra støy og forurensning" $(32,33)$. På samme måten som tilgang til en stille side av boligen, eller et roligere nabolag, kan virke plagedempende, kan det være at tilgang på stille rekreasjonsområder i lokalmiljøet kan ha betydning. Dette vet man foreløpig lite om, men en studie foretatt av Folkehelseinstituttet indikerer en sammenheng mellom støyplage hjemme og under rekreasjon i friluftsområder (34). Eksperimentelle undersøkelser hvor bl.a. blodtrykk er målt, viser at naturinntrykk virker stressreduserende sammenlignet med eksponering for urbane omgivelser $(35,36)$. Kartlegging og bevaring av stille områder som en viktig ressurs for individ og samfunn, er satt på dagsorden av både EU og WHO.

Det å for eksempel søke rekreasjon i et stille område kan betegnes som en form for mestringsstrategi. Lercher (30) fant en signifikant sammenheng mellom støyplage og ulike mestringsstrategier som å holde vinduer lukket, bytte vinduer, og flytte soverommet. En enda høyere andel enn de som faktisk hadde gjort slike tiltak, ønsket å gjøre det, men hadde ikke muligheten.

Mestring av støy kan være et spørsmål om bygningsstruktur og økonomi, som Lercher anfører som grunner for de som ikke hadde iverksatt tiltak $i$ hans studie. Men det vil også være et spørsmål om ressurser og overskudd i forhold til hva man ellers har av forskjellige typer belastninger i hverdagslivet. Wallenius (31) fant indikasjoner på en interaksjonseffekt mellom støyindusert stress og stress som følge av personlige prosjekter (f.eks. jobb-relatert stress): Sammenhengen mellom støyplage, aktivitetsforstyrrelser, og subjektive helseplager og somatiske symptomer var sterkest når graden av stress som følge av personlige prosjekter var veldig høy. Resultatene var imidlertid ikke entydige på tvers av støykilder, og datamaterialet var lite $(n=147)$. 


\section{PSYKISK HeLSE}

Effekter på psykisk helse innen støyforskning dekker alt fra blant annet symptomer på angst, nervøsitet, følelsesmessig stress og humørendringer til de mer generelle psykiatriske kategorier som psykoser og nevroser. Virkninger av støy på psykisk helse er ikke spesielt inkludert i modellen i figur 1. Støy er ikke antatt å være en direkte årsak, men kan tenkes å bidra til utviklingen og forverring av visse typer psykiske lidelser (3).

Flere tverrsnittsundersøkelser viser en sammenheng mellom støy og enkelte symptomer på redusert psykisk helse, som for eksempel økt forekomst av angst og depresjon, bruk av beroligende medikamenter og sovetabletter $(1,37,38)$. Det er imidlertid i svært varierende grad tatt hensyn til og kontrollert for faktorer som kan tenke seg å samvirke både med psykisk helse og områder med mye støy, som blant annet sosioøkonomisk status og støysensitivitet.

I en prospektiv studie med seks års oppfølging ble det ikke funnet noen sammenheng mellom vegtrafikkstøy og psykiatrisk sykdom, men det ble funnet en svak sammenheng mellom støy og angstsymptomer (39). I denne studien ble det kontrollert for støysensitivitet, sosio-demografiske faktorer samt fysisk og psykiatrisk sykdom ved studiestart. En annen studie viste ingen sammenheng mellom støyeksponering og psykisk helse, men symptomer på psykisk sykdom var større blant de som var svært støyplaget enn de som sa seg mindre plaget av støy (40).

Selv om flere undersøkelser kan vise til en sammenheng mellom støy, støyplage og forekomst av psykiske problemer, er det ingen entydig vitenskapelig støtte for at støy som gir støyplage også gir dårligere psykisk helse. Tilstrekkelig forståelse av det komplekse forhold mellom støyplage, mestring av støy og støysensitivitet og hvordan disse faktorene samvirker med psykisk helse mangler. Det er også begrepsmessige uklarheter med hensyn til psykiatrisk sykdomsklassifisering. Også andre metodiske svakheter ved flere av studiene gjør at endelige konklusjoner ikke kan trekkes (3).

\section{SUBJEKTIVE HELSEPLAGER}

Subjektive helseplager er plager der det ikke finnes noen objektive funn, som ofte kan være tilfelle for eksempel ved smerter i skuldre og rygg, hodepine, tretthet og fordøyelsesproblemer. Slike plager er svært utbredt, og mer enn halvparten av det samlede sykefravær er angitt å skyldes årsaker som er basert på subjektive utsagn fra pasientene (41). Det er vanskelig å utelukke alle tenkelige miljømessige og toksiske forklaringsmodeller for disse lidelsene, men samtidig er disse lidelsene for vanlige til at man kan forklare alle tilfeller som reelle toksiske eller somatiske fenomener (42). Individer med subjektive helseplager rapporterer at de er mer sensitive enn "normale" for miljøpåvirkninger, de blir lettere trette, og de har mer smerter enn andre.

Subjektive helseplager er ikke tatt med i modellen (figur 1) som er presentert av Babisch (13), men fordi støy kan være en stressfaktor, kan det tenkes at støy kan være medvirkende årsak til økte spenningstilstander i muskulaturen. Over lang tid kan dette føre til smerte- og betennelseslignende tilstander. Støy har også vært angitt å endre funksjonen/peristaltikken i mage- og tarmsystemet, og utskillelse av fordøyelsessekreter kan reduseres. Det er imidlertid ingen entydig understøttelse for dette i litteraturen. Noen funn, hovedsakelig fra tverrsnittsundersøkelser, refereres nedenfor, men mer kunnskap om mulig årsakskjeder trengs.

I en studie fra Østerrike (43) ble det funnet en korrelasjon mellom opplevd trafikkstøyplage, plage av bileksos og selvevaluert reduksjon av livskvalitet. Det ble videre funnet en sammenheng mellom opplevd luftkvalitet og tretthet, utmattelse, dårlig humør, nervøsitet, irritasjon i øyne og magesmerter. I Oslo er det funnet høyere hyppighet av fordøyelsesbesvær i områder med mye støy enn i roligere områder (44). I en annen norsk undersøkelse var det først og fremst de subjektive responsene på støy, støyplage og støysensitivitet, som viste en sammenheng med subjektive helseplager (21). Selve støynivået fra vegtrafikken viste ingen sammenheng med subjektive helseplager og søvnkvalitet. Denne studien hadde imidlertid et lite antall personer $(n=82)$ med relativt liten variasjon $\mathrm{i}$ støynivåer (LpAekv,24h fra $63 \mathrm{~dB}$ til $72 \mathrm{~dB}$ ). En svensk spørreundersøkelse gjennomført før og etter omlegging av vegtrafikk i tunnel, viste at etter omleggingen var det en signifikant reduksjon i antall som oppga irritabilitet, nervøsitet, depresjon, urolig mage og et ønske om å være alene, blant beboere nær den tidligere trafikkerte vegen (28). Støynivå fra vegtrafikken ble i dette området redusert med mer enn $10 \mathrm{~dB}$ i døgngjennomsnittlig støynivå (LpAekv, 24h). Også andre faktorer enn reduksjon $\mathrm{i}$ støynivået som for eksempel mindre forurenset luft og eksos, ble antatt å bidra til denne effekten. I en nylig publisert tverrsnittsundersøkelse av ca. 12000 personer rundt Schipol flyplass i Nederland ble det funnet en sammenheng mellom flystøynivå og hodepine og tretthet samt med selvevaluert generell helsestatus (45).

De undersøkelsene som har sett på sammenheng mellom støy og subjektive helseplager har brukt ulike metoder, både med hensyn til kartlegging av støyeksponering og ulike spørsmål om helseplager. Det er i varierende grad tatt hensyn til andre faktorer som påvirker forekomst av slike helseplager. Det kan være en opphopning av folk med helseplager i sterkt trafikkerte områder, men det kan også være slik at sensitive individer ikke flytter inn, eller flytter ut av slike områder. Det er imidlertid ikke sterke holdepunkter for en slik selv-seleksjon med hensyn til støysensitivitet (46). 


\section{VIRKNINGER PÅ SØVN}

I følge Statistisk sentralbyrå sin levekårsundersøkelse fra 1997 opplever om lag 5\% av befolkningen i Norge at de får sin søvn forstyrret av støy. Selv om det ikke er kjent hvorfor vi sover er det allment akseptert at søvn er en forutsetning for god fysiologisk og mental helse.

Søvn karakteriseres blant annet ved at hjernens elektriske aktivitet er endret i forhold til våken tilstand. Den elektriske aktiviteten gjenspeiler søvndybde og man skiller mellom 5 ulike søvnstadier. Hjernen kan tolke og bearbeide lyd også under søvn, slik at de fysiologiske responsene på lyd kan være de samme som $\mathrm{i}$ våken tilstand: økt hjertefrekvens, en temporær økning av blodtrykk og endret respirasjon $(47,48)$. Støypåvirkning under søvn har også vist å påvirke utskillelsen av stresshormonet kortisol, spesielt i første del av natten (49).

Søvn har i forskningssammenheng vært målt på en rekke ulike måter. Søvn kan blant annet måles ved hjelp av spørsmål om søvnkvalitet, hvor personen selv svarer på en rekke spørsmål knyttet til sin søvn og søvnkvalitet. En annen mye brukt og enkel metode er et såkalt aktimeter som festes til ankel eller håndledd for å registrere bevegelser under søvn. Ulempen ved den sistnevnte metoden er imidlertid at det ikke alltid er samsvar mellom ro og søvn eller bevegelser og våkenhet. En enkel måte å registrere oppvåkninger på er å få forsøkspersonen til å trykke på en knapp hver gang han eller hun har en oppvåkning. Denne metoden vil trolig underestimere antall oppvåkninger siden en person må være våken i noen minutter før man er klar over at man er våken. Den mest presise og objektive metoden for søvnregistrering er å måle hjerneaktiviteten direkte under søvn ved hjelp av EEG. Sammen med registrering av muskeltonus (EMG) og øyebevegelser (EOG) danner disse registreringene det beste grunnlaget for å skille mellom ulike fysiologiske søvnstadier.

Forstyrrelser av søvn regnes blant de mer alvorlige virkningene av støy. Problemer med nattesøvnen i trafikkerte områder er kjent gjennom en rekke undersøkelser. Umiddelbare virkninger av støy på søvnparametre er vanskeligheter med innsovning, endringer $\mathrm{i}$ søvnmønster og dybde og oppvåkninger i løpet av natten $(50,51)$. Dette fører til nedsatt subjektiv søvnkvalitet (52). Støyeksponering under søvn kan også gi sekundære virkninger eller ettereffekter dagen etter, som tretthet og redusert velvære, humør og yteevne (53). Også individuelle faktorer påvirker sammenhengen mellom støy og søvn. Eldre, personer med fysiske eller psykiske sykdommer og de med søvnproblemer fra før er spesielt utsatt for støyinduserte søvnforstyrrelser. Syke mennesker har større behov for hvile og kan derfor være spesielt følsomme for støy.

De langt fleste studier av støyforstyrret søvn er gjort under kontrollerte betingelser i et søvnlaboratorium. De senere år er det også gjort mer realistiske studier hvor man har målt søvn hjemme hos personer som bor i støyutsatte områder. Til dels svært ulike metoder for både støy- og søvnregistrering er brukt i de forskjellige undersøkelsene. En gjennomgang av mange av studiene frem til midten av 1990-tallet viste til dels store forskjeller i dose-responssammenhenger mellom studier gjennomført i laboratoriet og i en feltsituasjon, dvs. hjemme hos personer som er utsatt for støy om natten (54). Siden man fant at sannsynlighet for virkninger på søvn for et gitt støynivå var lavere $\mathrm{i}$ feltstudier spesielt med hensyn på vekking, ble det antatt at det foregår en tilvenning til støy under søvn. Undersøkelser som er gjort tyder på at det forekommer en viss tilvenning i forhold til antall oppvåkninger og subjektiv søvnkvalitet. Den fysiologiske tilvenningen med hensyn på økt hjertefrekvens som respons på støy under søvn er derimot dårlig. Dette er også interessant sett i lys av nyere forskning på støy og risiko for hjerte-karsykdom. Enkelte av disse studiene antyder at det er spesielt støyeksponering om natten som øker risiko for utvikling av sykdom $(55,56)$, hvor ufullstendig fysiologisk habituering til støy under søvn kan være en mulig virkningsmekanisme.

\section{EFFEKT PÅ HJERTE-KARSYSTEMET}

Fordi støy anses som en mulig stressfaktor er det fremsatt hypoteser om at kronisk støyeksponering kan føre til økt risiko for høyt blodtrykk, arteriosklerose og iskemisk hjertesykdom (fig. 1). De fleste studier av mulige sammenhenger mellom støy og hjerte-karsykdom er gjennomført for yrkesrelatert støy og flystøy. I en metaanalyse gjennomført i Nederland (57) med systematisk gjennomgang av 43 befolkningsundersøkelser, ble det funnet en relativ risiko for sammenhengen mellom flystøy og høyt blodtrykk på 1,26 (95\% KI: 1,14-1,39) for hver $5 \mathrm{~dB}$ (LAekv,t) økning i støyeksponering. Flystøy viste en positiv sammenheng med legekonsultasjon, bruk av medisin mot hjertekarsykdom og angina pectoris. I en større tverrsnittsstudie (58) ble det funnet en sammenheng mellom trafikkstøy og blodlipider, plasmaviskositet og glukosenivåer. Menn som var utsatt for mest trafikkstøy viste konsekvent de høyeste verdiene av disse målte parameterne, som indikerer høyere kardiovaskulær risiko. Effekten på blodtrykk var imidlertid ikke entydig. I en nylig publisert tverrsnittsundersøkelse av ca. 12000 personer rundt Schipol flyplass i Nederland ble det funnet en sammenheng mellom flystøynivå og bruk av medikamenter for hjerte-karsykdom/høyt blodtrykk, en oddsratio på 1,30 (95\% KI: 1,06-1,60) for hver $10 \mathrm{~dB}$ økning i flystøynivå. I denne studien var det kontrollert for en rekke faktorer som alder, kjønn, livsstilsfaktorer og utdanningsnivå (45). En tilvarende studie i Sverige antydet en dose-respons sammenheng mellom flystøynivå og forhøyet blodtrykk for eksponeringsnivåer over $55 \mathrm{~dB}$ ekvivalent støynivå og $72 \mathrm{~dB}$ maksimalt støynivå (LpAmaks) (60). 
Funnene fra disse studiene kan gjenspeile risikogrupper som er spesielt sårbare overfor støy. I en prospektiv studie med 6 års oppfølging fant man at allerede tilstedeværelse av sykdom (annen hjertesykdom/ kronisk sykdom) i stor grad så ut til å påvirke hvordan folk opplevde støy (20). For eksempel fant man en sterkere positiv sammenheng mellom støynivå og selvopplevd forstyrrelse av bl.a. hvile, innsovning og oppvåkning hos de med eksisterende sykdom, enn for hele utvalget slått sammen (både friske og syke). Det ble også funnet en sammenheng mellom støyplage og risiko for iskemisk hjertesykdom hos de friske, men ikke i gruppen med syke. Dette noe overraskende resultatet kan for øvrig gjenspeile en uttynning av en reell effekt på grunn av "recall bias".

Studier med bedre kartlegging av støyeksponering, sikrere data på forekomst av kardiovaskulær sykdom samt kontroll med andre sykdommer og potensielle årsaksfaktorer trengs før man kan trekke sikrere konklusjoner om virkninger av langvarig støypåvirkning på hjerte-karsykdommer.

\section{OPPSUMMERING/AVSLUTTENDE KOMMENTARER}

De akutte effektene av støy på helse og trivsel, som forstyrrelser av aktiviteter, hvile og søvn, er godt dokumentert. Hva dette betyr for helsa på lang sikt er derimot mer usikkert. Langvarig irritasjon over støy kan gi en vedlikeholdt stress- eller aktiveringsreaksjon, som kan påvirke utvikling av og forverring av sykdom. Støy er en uspesifikk stressfaktor og har derfor tilsvarende virkningsmekanisme som andre stressfaktorer.
Dette gjør det vanskelig å trekke slutninger fra epidemiologiske studier av støy og helse. I tillegg er de fleste slike studier tverrsnittstudier og mulige sammenhenger mellom støy og helse kan ikke uten videre tilskrives et risikofaktor-virkningsforhold. Dersom det er helseeffekter av støy utover plage, aktivitets-, prestasjons- og søvnforstyrrelser, er de sannsynligvis meget komplekse og forbundet med mer enn en risikofaktor. Flere longitudinelle studier, for eksempel intervensjonsstudier, med bedre kartlegging av støyeksponering samt kontroll med andre samvirkende og motvirkende faktorer vil være nyttige for å øke kunnskapen om sammenheng mellom støy og helse.

I den videre forskning bør man spesielt identifisere følsomme grupper. Det har vært en økende interesse for å undersøke støyvirkninger på barn, spesielt med hensyn til stress og virkninger på kognisjon og læring $\mathrm{i}$ en undervisningssituasjon. Det er videre et behov for mer kunnskap knyttet til mestringsstrategier i forhold til det å være utsatt for støy over lengre tid. I hvor stor grad venner man seg til støy over tid, og hva "koster" i så fall denne psykofysiologiske tilvenningen $\mathrm{i}$ form av negative helsevirkninger, er også spørsmål som krever avklaring.

Foreløpige analyser av samspillseffekter tyder på at det å være plaget av støy øker sannsynligheten for å være plaget av luftforurensning ved et gitt støynivå og omvendt. I tillegg er det holdepunkter for at både støy og luftforurensning øker risiko for hjerte-karsykdom. I det videre arbeid er det derfor også viktig å analysere samspillet mellom ulike miljøkomponenter og den relative effekt av de forskjellige kilder på folks helse.

\section{REFERANSER}

1. Stansfeld SA, Matheson MP. Noise pollution: non-auditory effects on health. Br Med Bull 2003; 68: 243-257.

2. Klæboe R. Samspill Trafikk, miljø og velferd. Rapport fra Transportøkonomisk institutt 645/2003.

3. Berglund B, Lindvall T, Schwela D, Kee-Tai G. Guidelines for Community Noise, Published on behalf of World Health Organization. Geneva, 2000.

4. Kolbenstvedt M, Klæboe R. Miljøplager i Norge 1997-2001. TØI rapport 592/2002.

5. Støyplage i Norge. 1999-2002. Reviderte tall. Veistøy på plagetoppen. SSBMagasinet. Statistisk sentralbyrå, 2004.

6. Langdon FJ, Griffiths ID. Subjective effects of traffic noise exposure, II: Comparisons of noise indices, response scales, and the effects of changes in noise levels. $J$ Sound Vibr 1982; 83: 171-180.

7. Brown AL, Hall A, Kyle-Little J. Response to a reduction in traffic noise exposure. J Sound Vibr 1985; 98: 235-246.

8. Horonjeff RD, Robert WE. Attitudinal responses to changes in noise exposure in residential communities. NASA Contractor Report 97-205813. Hampton, VA, NASA Langley Research Center, 1997.

9. Fidell S, Silvati L, Haboly E. Social survey of community response to a step change in aircraft noise exposure. $J$ Acoust Soc Am 2002; 111: 200-209.

10. Fidell S, Pearsons K. Sensitivity to prospective transportation noise exposure. Noise Control Eng J 2003; 51: 106-113.

11. Krog NH, Engdahl B. Annoyance with aircraft noise in local recreational areas, contingent on changes in exposure and other context variables. $J$ Acoust Soc Am 2004; 116: 323-333.

12. Støy: Helse og støy. Miljøstatus i Norge. Statens forurensningstilsyn, 2004.

13. Babisch W. The Noise/Stress Concept, Risk Assessment and Research Needs. Noise Health 2002; 4: 1-11.

14. Babisch W. Stress hormones in the research on cardiovascular effects of noise. Noise Health 2003; 5: 1-11. 
15. Aasvang GM, Uhlebæk C, Ursin H, Engdahl B. Trafikkmiljø, stress og helse. Rapport fra Folkehelsa 1999:3.

16. Maclure M. The case-crossover design: a method for studying transient effects on the risk of acute events. $\mathrm{Am}$ J Epidemiol 1991; 133: 144-153.

17. Ursin H, Murison R. Biological and psychological basis of psychosomatic disease. Oxford, Pergamon Press, 1983.

18. Hatfield J, Job RF, Hede AJ, Carter NL, Peploe P, Taylor R, Morrell S. Human response to environmental noise: the role of perceived control. Int J Behav Med 2002; 9: 341-359.

19. Kaneko K, Yamada I. Noise annoyance, stress and health effects. Proceedings of the Internet Symposium 2002. J Aviat Environ Res.

20. Babisch W, Ising H, Gallacher JEJ. Health status as a potential effect modifier of the relation between noise annoyance and incidence of ischaemic heart disease. Occup Environ Med 2003; 60: 739-745.

21. Nivison ME, Endresen IM. An analysis of relationships among environmental noise, annoyance and sensitivity to noise, and the consequences for health and sleep. J Behav Med 1993; 16: 257-276.

22. Guski R, Felscher-Suhr U, Schuemer R. The concept of noise annoyance: How international experts see it. $J$ Sound Vibr 1999; 223: 513-527.

23. Finegold LS, Finegold MS. Development of exposure-response relationships between transportation noise and community annoyance. J Aviat Environ Res 2002; 7, Supplement: 11-21.

24. Schultz TJ. Synthesis of social surveys on noise annoyance. J Acoust Soc Am 1978; 64: 377-405.

25. Miedema HME, Oudshoorn CGM. Annoyance from transportation noise: Relationships with exposure metrics DNL and DENL and their confidence intervals. Environ Health Perspec 2001; 109: 409-416.

26. Job RFS. Community response to noise - A review of factors influencing the relationship between noise exposure and reaction. J Acoust Soc Am 1988; 83: 991-1001.

27. Fields JM. Effect of personal and situational variables on noise annoyance in residential areas. $J$ Acoust Soc Am 1993; 93: 2753-2763.

28. Öhrström E. Longitudinal surveys on effects of changes in road traffic noise - annoyance, activity disturbances, and psycho-social well-being. J Acoust Soc Am 2004; 115: 719-729.

29. Klæboe R. The possible impact of the neighbourhood soundscape on exposure-effect relationships. I Proceedings Internoise 2001, The Hague, The Netherlands.

30. Lercher P, Kofler WW. Behavioral and health responses associated with road traffic noise exposure along alpine through-traffic routes. Sci Total Environ 1996; 189-190: 85-89.

31. Wallenius MAM. The interaction of noise stress and personal project stress on subjective health. $J$ Environ Psychol 2004; 24: 167-177.

32. Driver BL, Nash R, Haas G. Wilderness benefits: A state-of-knowledge review. 294-319. 1987. Fort Collins CO. Proceedings, National Wilderness Resarch Conference: Issues, State of Knowledge, Future Directions. USDA Forest Service General Technical Report INT-220. Lucas, R. C.

33. Vaagbø O. Den norske turkulturen: friluftslivets år 1993. FRIFO.

34. Krog NH, Engdahl B. Annoyance with aircraft noise in local recreational areas and the recreationist' noise situation at home. J Acoust Soc Am 2004 (in press).

35. Kaplan S. The restorative benefits of nature - Toward an integrative framework. J Environ Psychol 1995; 15: 169-182.

36. Hartig T, Evans GW, Jamner LD, Davis DS, Garling T. Tracking restoration in natural and urban field settings. J Environ Psychol 2003; 23: 109-123.

37. Miyakita T, Matsui T, Ito A, Tokuyama T, Hiramatsu K, Osada Y, Yamamoto K. Population-based questionnaire survey on health effects of aircraft noise on residents living around U.S. airfields in the Ryukyus PART I: An analysis og 12 scale scores. J Sound Vibr 2002; 250: 129-37.

38. Stansfeld SA, Haines MM, Burr M, Berry B, Lercher P. A review of environmental noise and mental health. Noise Health 2000; 2: 1-8.

39. Stansfeld S, Gallacher J, Babisch W, Shipley M. Road traffic noise and psychiatric disorder: prospective findings from the Caerphilly study. BMJ 1996; 313: 266-267.

40. Tarnopolsky A, Barker SM, Wiggins RD, McLean EK. The effect of aircraft noise on the mental health of a community sample: a pilot study. Psychol Med 1978; 8: 219-233.

41. Ursin H, Olff M. Stress: From synapse to syndrome. London: Academic press, 1993.

42. Malt UF. Somatization: an old disorder in new bottles? Psychiatrica Fennica 1991; 22: 79-92.

43. Lercher P, Schmitzberger R, Kofler W. Perceived traffic air pollution, associated behavior and health in an alpine area. Sci Total Environ 1995; 169: 71-74.

44. Hjortol R, Kolbenstvedt M, Nondal T. Trafikk og miljø; Utkast til rapport fra hovedanalysen. Oslo: Transportøkonomisk institutt, 1990.

45. Franssen EA, van Wiechen CM, Nagelkerke NJ, Lebret E. Aircraft noise around a large international airport and its impact on general health and medication use. Occup Environ Med 2004; 61: 405-413. 
46. Fields JM. Effects of personal and situational variables on noise annoyance: with special reference to implications for en route noise. NASA Report Number CR-189676, FAA Report Number FAA-EE-93-03 (Federal Aviation Administration, Washington, DC) 1992.

47. Öhrström E, Rylander R. Sleep disturbance by road traffic noise - a laboratory study on number of noise events. J Sound Vibr 1990; 143: 93-101.

48. Carter NL, Hunyor SN. A field study on traffic noise and cardiac arrythmia during sleep. In technical Papers: 4th Western Pacific Regional Acoustic Conference. Brisbane, Australia, 1991: 165-172.

49. Ising H, Ising M. Chronic cortisol increases in the first half of the night caused by road traffic noise. Noise Health 2002; 4: 13-21.

50. Eberhardt JL, Akselsson KR. The disturbance by road traffic noise of the sleep of young male adults as recorded in the home. J Sound Vibr 1987; 114: 417-434.

51. Griefahn B, Jansen G. EEG-responses caused by environmental noise during sleep their relationships to exogenic and endogenic influences. Sci Total Environ 1978; 10: 187-199.

52. Öhrström E. Longitudinal surveys on effects of changes in road traffic noise: effects on sleep assessed by general questionnaires and 3-day sleep logs. J Sound Vibr 2004; 276: 713-727.

53. Belojevic G, Öhrström E, Rylander R. Effects of noise on mental performance with regard to subjective noise sensitivity. Int Arch Occup Environ Health 1992; 64: 293-301.

54. Pearsons KS, Barber DS, Tabachnick B, Fidell S. Predicting noise-induced sleep disturbance. J Acoust Soc Am 1995; 971: 331-338.

55. Spreng M. Possible health effects of noise induced cortisol increase. Noise Health 2000; 2: 59-64.

56. Babisch W, Fromme H, Beyer A, Ising H. Increased catecholamine levels in urine in subjects exposed to road traffic noise: The role of stress hormones in noise research. Environ Int 2001; 26: 475-481.

57. van Kempen EEMM, Kruize H, Boshuizen HC, Ameling CB, Staatsen BAM, de Hollander AEM. The association between noise exposure and blood pressure and ischemic heart disease: A meta-analysis. Environ Health Perspect 2002; 110: 307-317.

58. Babisch W, Ising H, Gallacher JE, Elwood P, Sweetnam PM, Yarnell JWG, Bainton D, Baker IA. Traffic noise, work noise and cardiovaskular risk factors: The Caerphilly and Speedwell Collaborative heart disease studies. Environ Int 1990; 16: 425-435.

59. Rosenlund M, Berglind N, Pershagen G, Jarup L, Bluhm G. Increased prevalence of hypertension in a population exposed to aircraft noise. Occup Environ Med 2001; 58: 769-773. 